\title{
Panel Discussion Learning Object Definitions, Metadata, Instructional Design, and Repositories
}

\author{
Panelists \\ Jacques du Plessis, Alex Koohang, Jared Schaalje, Xiangming \\ "Simon" Mu, and Johannes Britz
}

jacques@sois.uwm.edu Koohang@uwm.edu ibschaal@gundluth.org mux@sois.uwm.edu britz@sois.uwm.edu

\section{Introduction}

The many promises of learning objects (readily available quality instruction, reducing cost of production, personalized learning, interoperability, reusability, discoverability/accessibility, scalability, durability, content customization, and many more) have been the talk of the e-learning community in recent years. Higher education institutions have begun to capitalize on these promises by adopting, developing, and deploying learning objects in e-learning instruction.

\section{Purpose}

The purpose of this panel is to create a dialog with four major themes affecting learning objects. They are: learning object definitions, learning object metadata, learning object instructional design, and learning object repositories.

\section{Themes}

\section{Learning Object - The Many Definitions}

There are many definitions of learning objects. These definitions, in general, argue about learning object's purpose and whether a learning object is digital only or a combination of digital and nondigital (Cisco Systems, 2001; Downes, 2003; Friesen, 2001; IEEE, 2000; Quinn \& Hobbs, 2000; Sosteric \& Hesemeier, 2002; Wiley, 2000). The panel will attempt to provide a comprehensive evaluation of these definitions.

\section{Learning Object Metadata}

Metadata is information about information. Metadata records the characteristics of learning object's content. Organizations such as ADL (http://www.adlnet.org/), CanCore (http://www.cancore.ca/indexen.html), Dublin Core (http://dublincore.org/), IEEE LTSC LOM

Material published as part of these proceedings, either on-line or in print, is copyrighted by Informing Science. Permission to make digital or paper copy of part or all of these works for personal or classroom use is granted without fee provided that the copies are not made or distributed for profit or commercial advantage AND that copies 1) bear this notice in full and 2) give the full citation on the first page. It is permissible to abstract these works so long as credit is given. To copy in all other cases or to republish or to post on a server or to redistribute to lists requires specific permission from the publisher at Publisher@InformingScience.org (http://ltsc.ieee.org/), and IMS (http://www.imsproject.org/) are involved in developing standardized metadata schemas and best practice metadata standardization. Metadata standardization enhances attributes such as discoverability, accessibility, manageability, and interoperability of 
learning objects. These attributes promote usability. The panel will attempt to delineate pros and cons of various metadata standardizations.

\section{Learning Object - Instructional Design}

A learning object is made of the content and the metadata. The content can be text, image, audio, video, and/or animation. The metadata is the information about the characteristics of the content. Downes (2003) asserts that a learning object is a learning object when it used for learning and that it has pedagogical value.

A learning object's educational value rests within the content that is created with appropriate and sound instructional design (Koohang \& du Plessis, 2005). The panel will attempt to present the value of instructional design for the content of learning objects. The panel will also present various instructional design theories and principles suitable for learning objects.

\section{Learning Object Repositories}

Repositories are used to store learning objects. There are two types of repositories for learning objects. The first type contains both the learning object content and the metadata. This repository locates and delivers learning objects. The second type consists of only the metadata. The actual learning object content is located at another place. This repository locates learning objects. There are many learning object repositories build specifically for use in higher education. Examples of these repositories include Apple Learning Interchange (http://ali.apple.com/ali/resources.shtml), CAREO (http://careo.netera.ca), Educational Object Economy (http://www.eoe.org), Educational Software Components of Tomorrow (http://www.escot.org), Filamentality (http:/www.kn.pacbell.com/wired/fil), Gateway to Educational Materials (http://www.thegateway.org), MERLOT (http://www.merlot.org/Home.po), OpenCourseWare MIT (http://ocw.mit.edu/index.html), and Wisconsin Online Resource Center (http://www.wisconline.com). The panel will discuss these repositories and their applications for higher education institutions. The panel will also discuss pros and cons of these repositories.

\section{The Structure of the Panel}

The panel will consist of four themes in the area of learning objects: definitions, metadata, instructional design, and applications. Panelists will present one theme at a time. The audience will be invited to ask questions and contribute to the discussion.

\section{References}

Cisco (1999). Cisco Systems reusable information object strategy. Retrieved November 14, 2004, from http://www.cisco.com/warp/public/779/ibs/solutions/learning/whitepapers/el_cisco_rio.pdf

Downes, S. (2003). Designing learning objects. Retrieved November 14, 2004, from $\mathrm{http} / /$ www.learnscope.anta.gov.au/learnscope/golearn.asp?category=11\&DocumentId=4077

Friesen, N. (2003). Three objections to learning objects. Retrieved November 14, 2004, from http://www.learning-objects.net/modules.php?name=News\&file $=$ article $\&$ sid $=8$

IEEE LTSC LOM (2000). Learning object metadata. Retrieved November 14, 2004, from http://ltsc.ieee.org/wg12/

Koohang, A. \& du Plessis, J. (2005). Placing and securing learning in learning objects. Unpublished Manuscript.

Quinn, C \& Hobbs, S. (2000) Learning objects and instructional components, Educational Technology and Society, 3 (2). Retrieved November 14, 2004, from http://ifets.ieee.org/periodical/vol_2_2000/discuss_summary_0200.html 
Sosteric, M., \& Hesemeier, S. (2002). When is a learning object not an object: A first step towards a theory of learning objects. International Review of Research in Open and Distance Learning, 3 (2), Retrieved November 14, 2004, from http://www.irrodl.org/content/v3.2/soc-hes.html

Wiley, D.A. (2000). Connecting learning objects to instructional design theory:A definition,a metaphor, and a taxonomy.In D.A.Wiley (Ed.),The Instructional Use of Learning Objects: Online Version . Retrieved November 15, 2004, from http://reusability.org/read/chapters/wiley.doc

\section{Panelists Biographies}

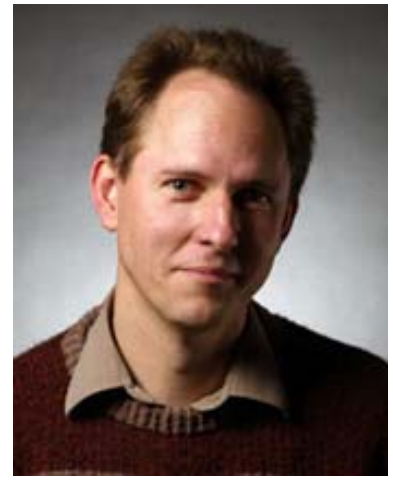

Jacques du Plessis' PhD is in Instructional Technology. He is an assistant professor in the School of Information Studies at University of Wisconsin - Milwaukee, USA. He has been teaching foreign language at the college level for more than 15 years. Since the 1980's he has been designing and developing computer based instructional software. He has experience with XML-based content management and online collaborative environments to develop instruction. Dr. du Plessis is presently researching the concepts of granularity and reusability.

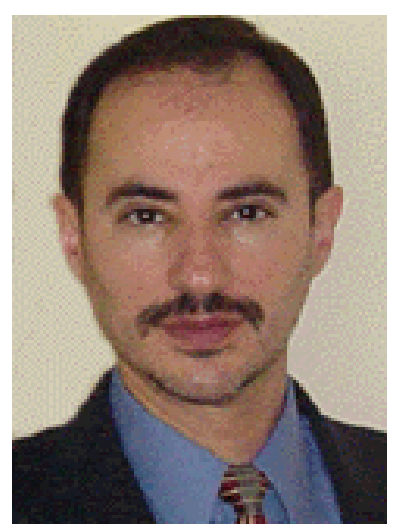

Alex Koohang, Ph.D. is Director of Undergraduate Programs, School of Information Studies, University of Wisconsin at Milwaukee. His 20 years of experience in higher education include stints as a faculty member, program director, curriculum product manager, visiting professor, and division director. He has authored or co-authored many papers. Dr. Koohang's current research interest includes e-learning, learning objects, and usability.

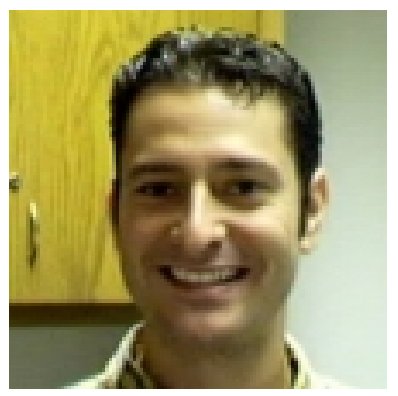

Jared Schaalje has a master's degree in Instructional Technology, and is currently working on a Ph.D. in Instructional Design for Online Learning. He is currently working for the Gundersen Lutheran health care system as a web-based instructional designer and developer. His work for the health care enterprise includes developing over 50 SCORM/AICC compliant learning objects, which are currently running in the organization's learning management system. Jared has recently completed a book for quickly producing high quality, theory-based online learning modules. His book will soon be available from Trafford Publishing. 


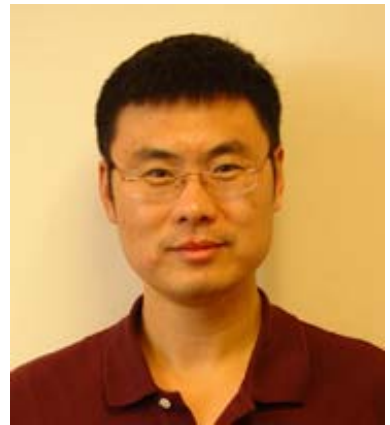

Xiangming "Simon" Mu is an assistant professor in the School of Information Studies at the University of Wisconsin-Milwaukee. His current research areas include human-computer interaction, digital library, interface design, metadata, distance learning, multimedia, video streaming, internet architecture and design.

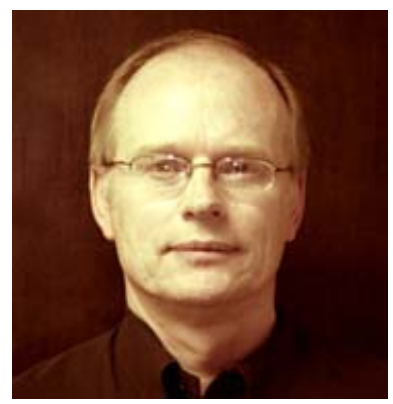

Johannes Britz is a professor in the School of Information Studies at the University of Wisconsin-Milwaukee. He also teaches at the University of Pretoria, South Africa and the University of Amsterdam in the Netherlands. He specializes in the fields of information ethics, knowledge management and information for development. He serves on a number of international committees and acts as consultant for a number of governments in Africa as well as the European Union. Dr. Britz is currently researching the role of knowledge management for learning object. 